\title{
Migration, acculturation and culture change in western temperate Eurasia, 6500-5000 cal BC
}

\author{
Detlef Gronenborn \\ Römisch-Germanisches Zentralmuseum Mainz, Johann-Wolfgang-Goethe-Universität, Frankfurt am Main, D \\ gronenborn@em.uni-frankfurt.de
}

\begin{abstract}
After the introduction of the pottery tradition of La Hoguette and contemporaneous research on Earliest LBK about 10 to 15 years ago, research on the spread of farming in Central Europe had somewhat stagnated; there were hardly any major advances in factual knowledge, nor could theoretical models be refined. In the last few years, however, an abundance of new data has appeared, partly deriving from botanical and anthropological analyses. Furthermore, newly available results from excavations in European Russia widen our understanding of the manifold and complex changes occurring during the latter $7^{\text {th }}$ and $6^{\text {th }}$ millennium cal $B C$.
\end{abstract}

IZVLEČEK - Po uvedbi keramične tradicije La Hoguette in sočasnih raziskavah zgodnje LTK pred okoli 10 do 15 leti, so raziskave širjenja kmetovanja v srednji Evropi nekoliko zastale; skoraj nobenega napredka ni bilo v faktografskem znanju, niti nismo izboljševali teoretičnih modelov. V zadnjih letih pa se je pojavilo veliko novih podatkov, ki izvirajo deloma iz botaničnih in antropoloških analiz. Poleg tega so sedaj dostopni tudi rezultati izkopavanj v evropskem delu Rusije, kar razširja naše razumevanje raznovrstnosti in kompleksnosti sprememb, ki so se dogajale $v$ času poznega 7 . in $v 6$. tisočletju cal BC.

KEY WORDS - Central Europe; Eastern Europe; Neolthic; forager-horticulturists; acculturation

\section{MODELS OF NEOLITHIZATION}

If one looks at the traditional cartographic representations of the spread of farming in Europe there is always a preponderance of Central Europe, the Balkans and the Near East (Fig. 1 a-c). Supposed migrations or lines of diffusion are often indicated by arrows which are generally oriented in a south-easterly to north-westerly direction.

Only very recently do maps show a spread from southern France towards the Northeast, into Central Europe. This spread is related to the geographical distribution of La Hoguette (LH) pottery, a ware which is found in association with a Late Mesolithic lithic tradition and a subsistence system in which people practised hunting and gathering combined with smallscale horticulture (Jeunesse 2000; 2001).
Completely barren of any cultural changes, apparently, are the east European territories, the taiga, the deciduous forests, and the steppes of what is now Russia, Belarus, and the Ukraine. As will be shown below, this bleakness does not correspond to prehistoric reality, but much more to the effects of the "iron curtain", although this fell in 1989.

In this paper, I will present new advances in knowledge on the "classic" themes of Neolithization in Central Europe: the LBK expansion and the reaction of indigenous populations, but I will also incorporate new data from Eastern Europe and attempt to expand the conception of the process generally termed the "Neolithization of Europe". 


\section{LBK Expansion}

I will begin with the spread of the Linear Pottery Culture or German "Linienbandkeramik" (LBK). An abundance of new data has not only altered our concepts of its distribution, but also added new insights into the process of interaction with indigenous societies.

The state of research up until the late 1990ies has been summarized in Gronenborn (1999; see also Bogucki 2000). Since then, new data has evolved from typological studies, as well as palaeobotanical and dendrochronological work. As to the question of the origins of the earliest LBK (eLBK; Meier-Arendt's [1972] phase I), new material has been published by Bánffy $(2000 a ; 2000 b ; 2000 c)$. She discovered a pottery tradition with Starčevo and eLBK elements at the site of Pityerdomb in Hungary, SW of Lake Balatón. However, the associated ${ }^{14} \mathrm{C}$-dates appear relatively late in the eLBK sequence, so it is not impossible that Pityerdomb represents an acculturation phase which evolved when eLBK expanded southward into the lands between Lake Balaton and the Drava River. The typological origin of LBK ware has recently been delineated by Petrasch (2001.16). Like Pavúk (1994), he considers the territory encompassing the Bakönyi and NE Transdanubia as the most likely area of origin. It remains, however, to be clearly noted that the whole of Transdanubia is an area where only a few small excavations have yet been undertaken, and certainly the question of the exact locaton of the interaction between the Starče-

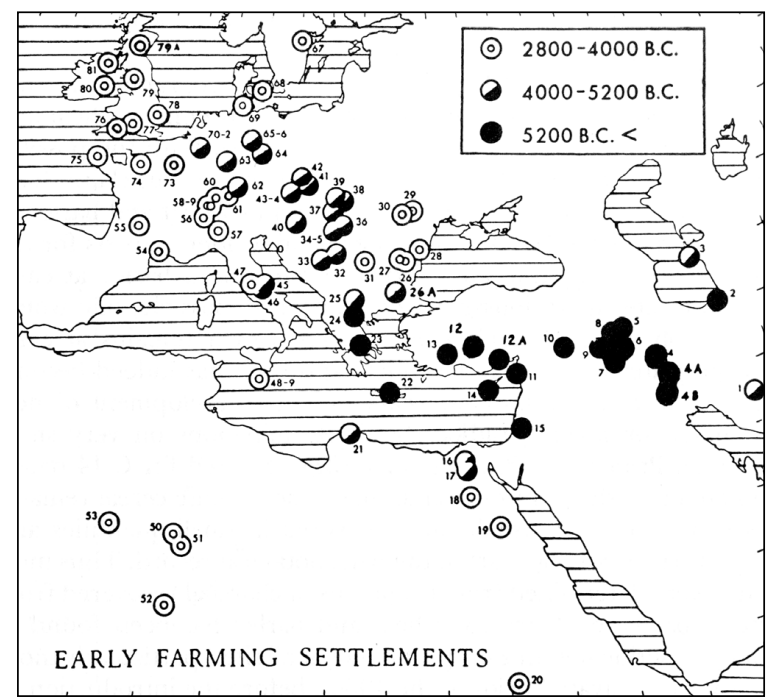

Fig. 1. Cartographic representations of the spread of pottery and farming (after Piggott 1963 (upper); after Uerpmann 1983 (upper right); after Zimmermann 2002 (right down). vo culture and the eLBK needs to be further investigated. Nevertheless, from this still somewhat hypothetical core area in Transdanubia eLBK expanded in a north-westerly direction. Two dates are available for its advent in western areas, one stemming from the eLBK well at Mohelnice (Tichy 1998), which has now produced a dendrochronological date of around/after $5540 \pm 5$ den BC and not later than $5460 \pm 5$ den BC (Schmidt, Gruhle 2003; pers. communication B. Schmidt). The other date comes from the eLBK burial at the site of Schwanfeld near Würzburg, which was analyzed by conventional ${ }^{14} \mathrm{C}-$ dating, and revealed a date of 5560-5480 cal BC (Stäuble 1995 [HD-14219 $6580 \pm 20 \mathrm{BP}]$ ).

Both dates are considered to be the earliest absolute points in time for the westward expansion of eLBK. The eastward expansion around the Carpathian Mountains into Poland and further towards Ukraine can be dated with ${ }^{14} \mathrm{C}$-measurements from the sites of Stolno (5440-5310 cal BC) and Boguszewo 41 (5480-5250 cal BC/5440-5270 cal BC, both at $68,2 \%$ Std Dev), both located in the Chelmo region along the lower Vistula River (Bednarz 2001). Absolute dates for the beginning of eLBK in Transdanubia remain problematic. Recently obtained ${ }^{14} \mathrm{C}$-dates and a combined correspondence analysis of eLBK pottery from the sites of Neckenmarkt and Strögen in Lower Austria produced rather young dates for the proposed first settlement phase at these locations, namely 5490-5080 cal BC ([at 68, 2\% Std Dev] Lenneis, Stadler 2002). It needs, however, to be mentioned that the Neckenmarkt assemblage does

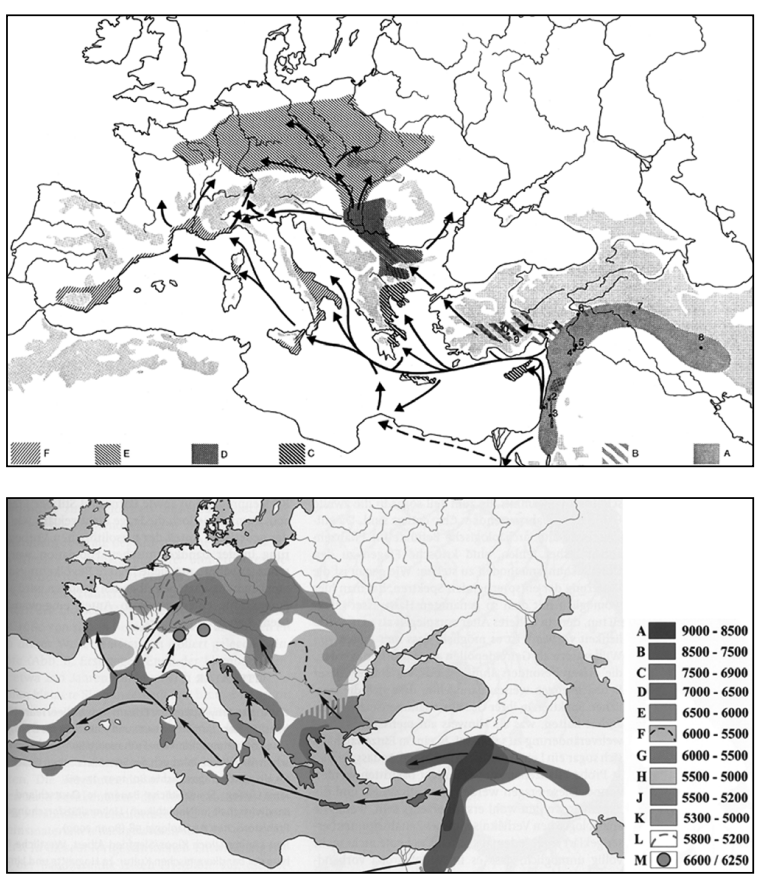


not represent the earliest typologically discernable eLBK ware in the region (Lenneis 2001). The earliest secure dates for the westernmost extension of eLBK settlements in the Rhine-Main confluence region have recently come from dated pollen profiles from the Wetterau region north of Frankfurt am Main. The changes to vegetation typically wrought by eLBK settlements date to 5470-5310 cal BC and 5620-5480 cal BC (Schweizer 2000.95-97). This is slightly earlier than anticipated from archaeological material from the region, which seemed to begin after 5400 cal BC (Gronenborn 1997.136; Stäuble 1995). In any case, judging from the present evidence, eLBK seems to have expanded into the larger part of its distribution area by the $55^{\text {th }}$ century cal BC (Fig. 2).

The new data calls for a reconsideration of the hypothetical three-step expansion model proposed earlier (Gronenborn 1994; 1997). Apparently, the LBK expansion cannot be subdivided archaeologically by ${ }^{14} \mathrm{C}$-dates. The process seems to have taken place within a time frame of 100 years, during which more than $800 \mathrm{~km}$ were crossed. A rapid spread of groups originating in Transdanubia over wide territories is also indicated by the distribution system of Szentgál radiolarites towards the West (Fig. 2). Recently Petrasch (2002.144) has suggested a similar model on the basis of stylistic similarities of so-called Idols from Frankfurt-Niedereschbach and Vel'ký Grob in SE Slovakia. He proposed that these figurines would represent ancestors who were worshipped by individual lineages. Members of these lineages would have lived in different settlements between the Rhine and Middle Danube valleys. Ancestor figurines or not, it is not improbable that lineages expanded and that contacts visible in material culture such as pottery ship lines (Gronenborn 1997; 1999).

To further understand how eLBK societies were organized and how the expansion proceeded, it may be worthwhile looking at what ethnography has to offer. Sahlins (1961) developed the concept of the segmentary linage as a well-adapted form of sociopolitical organisation. Under stress these societies would organize themselves under the leadership of capable and charismatic war leaders and would decentralize again after the conflict was over. This short-term military superiority would then be advantageous in conflicts with "tribal" societies into whose territory the society would expand. Modern ethnography has developed more subtle modes of explanation, one example being that of the segmentary Dagara in today's Burkina Faso and Ghana (Kuba

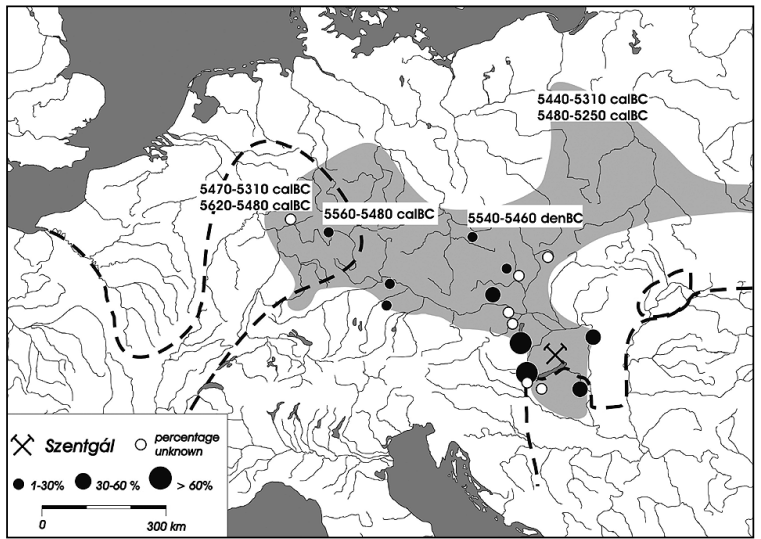

Fig. 2. Distribution of Earliest LBK. Extension of eLBK is shaded, dashed lines represent the pottery traditions of La Hoguette in the West and Starčevo-Körös and Szatmár in the East respectively (modified after Gronenborn 1999).

2001). Over a period of about 200 years the Dagara, starting from a core territory, expanded into a region of several hundred square kilometres. They invaded the lands of surrounding groups which were organized on the same socio-political and economic level, segmentary farming societies. The advantage of the Dagara, however, was their tradition of establishing ritual ties to the terrain, and thus gaining control of the rights of utilization of this land. The land is ritually administered by an earth priest, who maintains a shrine, often an accumulation of rocks at a prominent tree. This earth priest is responsible for the administration of arable land and the territory in general; the land is divided up into 'power spheres' of such shrines. There are older, more powerful shrines, and more recently founded ones with a less intense ritual domination. While most of the groups in the area do have the institution of earth priest, the Dagara seem to maintain a more mobile and more flexible way of handling the concept of earth shrines and were thus capable of ritually dominating larger portions of land (Kuba 2001.424).

Dagara expansion proceeded in three steps. First, small groups migrated into new territories and settled peacefully among the local population. Perhaps the first motive for expansion was the search for better farming conditions (Kuba 2001.422). In any case, in the second step the Dagara-communities expanded and conflicts with the local population evolved. In the third phase, previously uninhabited portions of the land were settled, and the expansion was fuelled by the fissioning of communities (Goody 1958), and often pioneer settlements are founded by hunters. These hunters are then followed by their kin or friends. Certainly, there are quite a number of 
differences between the eLBK and the West African analogy, but generally this example might help to illustrate expansionist societies and their interaction with neighbouring local groups.

\section{Indigenous Components in Central Europe}

New evidence is also available for the local Terminal Mesolithic populations along the western fringes of the eLBK territory: the above mentioned pollen profiles in the Wetterau show indications of an economy based on foraging, with additional horticulture and small-scale animal husbandry of for instance sheep and/or goat already before the advent of the classical LBK pollen profile markers (Schweizer 2001). A slight, but discernible increase in heliophylic plants during the Middle Atlantic is evident; the dense forests were artificially opened. Also, small charcoal particles and burned pollen increase, so some kind of fire management may be supposed. Plantago and poppy indicate the presence of humans, and since the variety of poppy (Papaver setigerum) is indigenous to southern France it is clear that these economic innovations would have had their origins in regions in this direction. This makes it likely that the manufacturers of the La Hoguette pottery, which has stylistic ties to southern France, were responsible for the environmental changes. These indications of small scale horticulture and animal husbandry date between 5700 and $5500 \mathrm{cal} \mathrm{BC}$.

Pre-LBK farming had already been proposed by ErnyRodmann et al. (1987) and is now supported by new data from the Loire valley in France (Visset et al. 2002). It becomes increasingly evident that Late Mesolithic populations were practising some kind of horticulture and perhaps husbandry already during the latter half of the $7^{\text {th }}$ millennium cal BC. This may somehow contradict the recent proposition of a relatively late onset of farming along the West Mediterranean coast. According to Zilhão's (2001) interpretation of ${ }^{14} \mathrm{C}$-dates on short-lived material at early Neolithic sites in Italy, southern France, Spain, and Portugal, a rapid onset of the Neolithic package around 5500 cal BC or shortly thereafter seems more likely than earlier scenarios of a gradual shift from hunting/gathering to the fully evolved Neolithic. The question is how to resolve this contradiction: there are indications of small-scale horticulture in temperate Europe, possibly already during the latter part of the $7^{\text {th }}$ millennium, and husbandry and small-scale horticulture after $5700 \mathrm{cal} \mathrm{BC}$, whereas the Mediterranean coastline seems to have been colonized by farmers only after $5500 \mathrm{cal} \mathrm{BC}$. This ap- parent contradiction should be tackled in future research. It remains to be noted that also in Central Europe a discussion around the validity of "traditional" ${ }^{14} \mathrm{C}$-dates and AMS measurements on short-lived materials has been going on for about a decade and a consensus has not yet been reached (Gronenborn 1997; Lenneis, Stadler, Windl 1996; Lenneis, Stadler 2002; Stäuble 1995; Stöckli 2002).

In Central Europe, botanical, sedimentological, and zoological analysis of the materials recovered at the LH site of Stuttgart-Bad Cannstatt has brought an abundance of new insights into the economy of the Terminal Mesolithic forager-horticulturists. The site was discovered and tested already during the 60ies by W. Taute and his team (Brunnacker et al. 1967), but at the time LH was still unknown, so the material was left uninterpreted. After pottery fragments of the first excavation were identified as LH by A. Tillmann another small excavation was started. Both test pits had only a very small extension, since the archaeological material is deposited beneath travertine layers and located in the zoological-botanical garden of Stuttgart, hence it was impossible to conduct large-scale excavations. Four cultural layers were identified, of which the lowest one (WIL 1) is dated through organic remains from a LH pottery fragment. The date is $5460-5290$ cal BC $(68,2 \%$ : UtC-5450 $6353 \pm 45 \mathrm{BP}$ ) and thus contemporaneous with eLBK in the region, which should date after 5500 cal BC (Meurers-Balke, Kalis 2001.634). The excavations produced a small number of artefacts: apart from the above-mentioned pottery fragments, bone harpoons and lithic material were found (Fig. 3). Of interest is a fragment of a so-called pointe de Bavans, a triangular arrowhead which is also known from the LH layers of the site of Bavans (Jacottey 1997.323, Fig. 4c). Botanical analysis showed that the location was continuously visited during the spring and fall. The seasonal human occupation was not long-lasting, but was intensive enough to have brought about slight alterations in the natural plant cover, which is supposed to have been dense, although large trees would not have grown immediately on the location. Thus, heliophytic plants increased, as well as snails which are adapted to open vegetation (Kalis et al. 2001.666). Some wheat pollen (Triticum aestivum type) shows that domesticated plants were processed at the site, but the amount of cereal pollen is too low to have resulted from permanent gardens or fields. Probably the cereals were brought in from other locations. Additionally to cereal pollen some pollen from Papaver setigerum was found, as mentioned above, a plant 
of southern French origin. Bones of sheep/goat show that domesticated animals were killed and consumed at the site; other bone material comes from the typical wild fauna of the area, mostly red and roe deer. The archaeological as well as botanical, zoological and sedimentological analyses all present a picture of an economy which was largely based on hunting and gathering, but which was supplemented by certain "Neolithic elements": animal husbandry and small scale horticulture. ELBK sites do exist in close proximity to Bad Cannstatt, but there are no clear indications of any artefacts of LBK origin at the site. Only wheat might have been exchanged from a settlement with a farming economy (Strien, Tillmann 2001).

The situation at Bad Cannstatt does not reveal any clear indications for farmer-forager interactions, but such evidence is available from a number of other sites along the Rhine River, mainly Bruchenbrücken (Gronenborn 1990; 1999). More information on such possible interaction has come from other sites: recent strontium isotope analyses on skeletal material from a number of LBK burials also show some amount of migration within the population of LBK communities (Price et al. 2000; Bentley et al. 2002). Three burial grounds were investigated: the LBK Phase II burial ground of Flomborn, the Late LBK burial ground of Schwetzingen, and the Middle-Late LBK burial ground of Dillingen. In Flomborn both male and female immigrants exceed $60 \%$, while the rate of male immigrants in the later cemeteries is notably lower than that of females. This shows that in early LBK communities a considerable number of individuals did not grow up in those settlements where they died. Where they had come from is still unclear, but it is quite possible that they had grown up in the highlands which surround the Rhine and Neckar valleys. These highlands might have been exploited by groups who belonged to a remaining forager population. In later centuries migrants might have come from other LBK settlements, or huntergatherer populations who lived further to the west, as there LH pottery is still found in LBK settlements (Lüning, Kloos, Albert 1989). Moreover, Jeunesse $(2000 ; 2001)$ was recently able to demonstrate that Alsatian LBK sites show a continuous influence from local Mesolithic groups until the end of the Early Neolithic. This influence is particularly visible in ceramic decoration, which would indicate that forager women had joined LBK village communities (Fig. 4).

But contact with hunter-gatherer populations was not only directed towards the West. An eLBK pit at

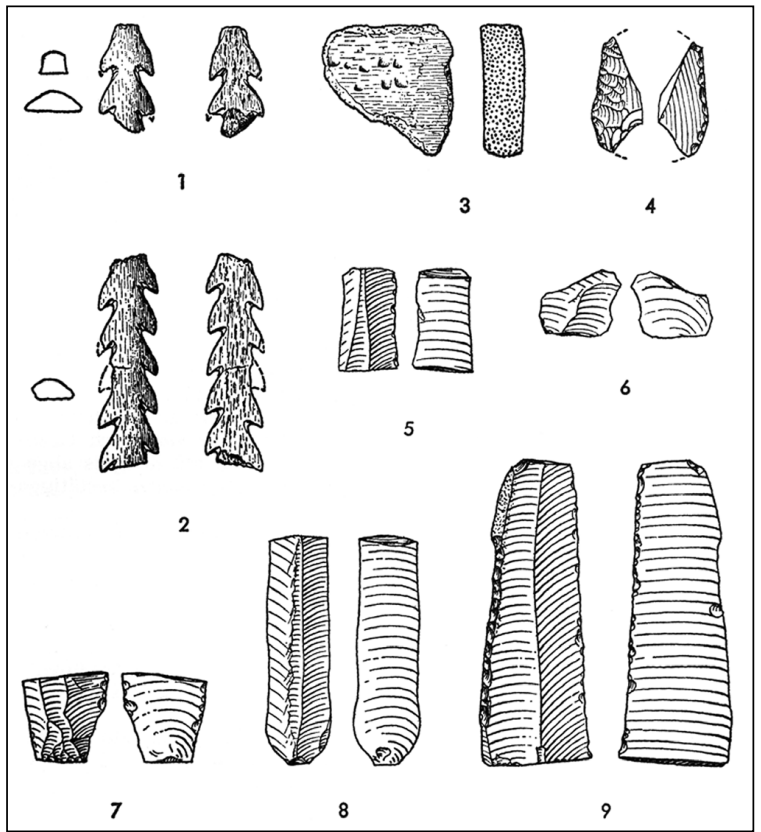

Fig. 3. Archaeological material from Stuttgart-Bad Cannstatt (after Brunnacker et al. 1967).

Brüchenbrücken contained a specific type of arrowhead, an oblique transverse arrowhead, which was manufactured out of erratic flint (Fig. 5). The blade was much broader than those usually found in eLBK assemblages (Gronenborn 1997.99). This type does have numerous parallels in the northerly European lowlands and in Denmark, and is typically found on Kongemose sites (e.g. Hartz 1985). Erratic flint is quite abundant on eLBK sites (Gronenborn 1997. 114 ) and indicates that contacts existed far into territories not traditionally occupied by LBK farming settlements. This interaction towards the north is not new, but traditionally exchange mechanisms and cultural transfer were viewed to have been directed from the southern Neolithic settlements towards the North. Hence farming is believed to have originated from the Early and Middle Neolithic groups in the South (Hartz, Heinrich, Lübke 2000; Kalis, MeurersBalke 1998). Until very recently many scholars would have argued that the typical pottery of the Ertebølle and Swifertbant-traditions also would have been influenced from southern Central Europe.

\section{The Spread of Pottery in Eastern Europe}

However, the process of the Mesolithic-Neolithic transition in the European lowlands might have been much more complex. In several recent articles Timofeev $(1998 a / 1998 b)$ has argued that the eastern and western Baltic areas were linked through cultural contacts and he has shown that Ertebølle pottery has close stylistic and technological links with 
Polish and West Russian traditions. This general idea, still widely neglected in western scholarly circles, had already been expressed by V. I. Danilenko (1969), who saw resemblances between Ertebølle and the Ukrainian Surks-Dnepr tradition. Indeed, recent research in Russia has produced new ${ }^{14} \mathrm{C}$-Dates for a number of ceramic traditions, some of which seem to date to the early $7^{\text {th }}$ millennium cal BC. This is the case for the so-called Elshan tradition, which is distributed along the River Samara and the Lower Volga (Mamonov 2000). The published dates group around the turn of the $8^{\text {th }}$ to the $7^{\text {th }}$ millennium cal BC. According to Mamonov (2000) two different phases can be distinguished, of which the earlier one still dates to the late Boreal. Vessels of this phase have straight or S-profiled walls, and pointed or flat bases (Fig. 6). Sites are dispersed along river courses and can be interpreted as either just briefly occupied special task camps or larger base camps. But it is unlikely that the latter were occupied all year round. So far there is no evidence for any permanent habitation structures; shelters should have been light and of an ephemeral character. Subsistence was based on mollusc gathering (Unionidea), fishing, and hunting forest and steppe species; there clearly is no evidence of any domesticated plants.

The craft of pottery manufacturing spread towards the West and Northwest and reached the Upper Volga area after $6000 \mathrm{cal}$ BC. Pointed base vessels are also known from the Bug-Dniestr tradition (BDK), which should date between 5700 and $5000 \mathrm{cal} \mathrm{BC}$ (Wechler 2001; Zvelebil and Dolukhanov 1991). But BDK pottery is equally influenced by Körös-Cris pottery from the South-West and also aspects of the Neolithic economy - cattle, sheep/goat, einkorn, emmer - seem to have come from this direction (Wechler 2001). Although some habitation structures are documented for the BDK, it is unclear whether settlements were occupied throughout the year. The economy was based on hunting and gathering, and farming was practiced on a minor scale. In a later phase there are also contacts with neighbouring LBK settlements.

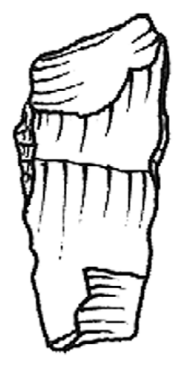

More northerly pottery traditions have no indications of a farming economy. Pottery is embedded in cultural entities whose members continue with

Fig. 5. Oblique transverse arrowhead from Bruchenbrücken (after Gronenborn 1997).

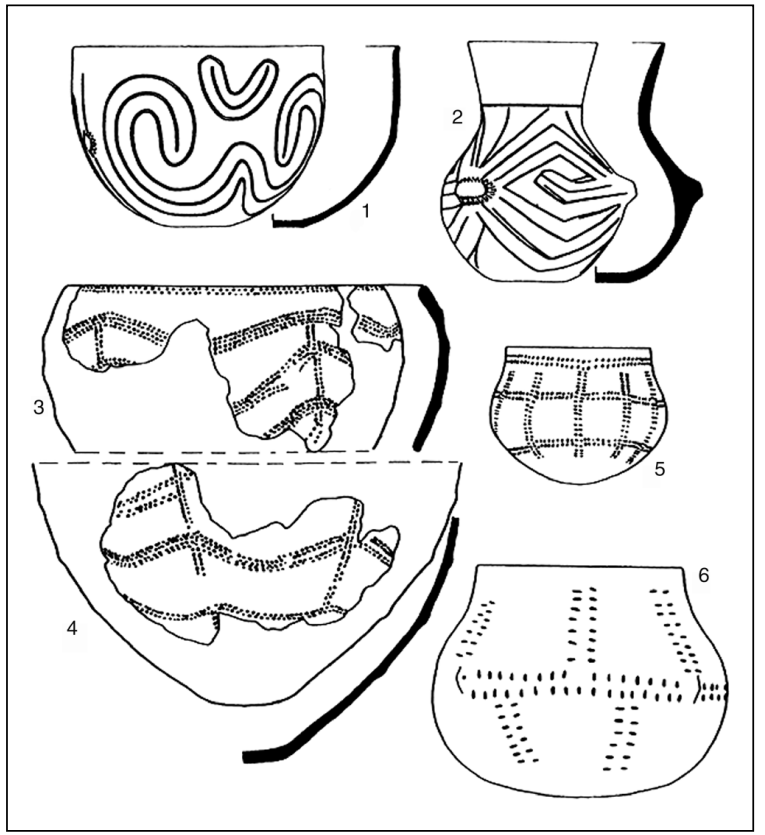

Fig. 4. LBK and La Hoguette vessels with "hybrids forms" (after Jeunesse 2001).

their traditional hunter-gatherer way of live. Nor are there indications of year-round occupied settlements. Sites along the river courses in the Russian forest belt all show that the economy depended solely on hunting and gathering. Burials, for instance at Zvejnieki in northeastern Lithuania (Zagorskis 1987) belonging to the Narva and Comb-and-Pit traditions, are accompanied by hunting gear such as bone harpoons, points and lithic arrowheads. Domestic plants, emmer and cannabis, are only evident from the $3^{\text {rd }}$ millennium onwards. Also in another area, along the Western Dvina - the location of the Serteya, Rudna and Usvyaty traditions - domestic plants appear only very late in the sequence, around the last centuries of the $3^{\text {rd }}$ millennium cal $\mathrm{BC}$, at the time of the local Zhizhtsia- and North-Belarusian traditions. The latter is considered to be a local variant of the pan-European Corded Ware horizon. At this point domestic animals appear in the record, such as sheep/goat, cattle, pig, and horse (Dolukhanov et al. 1989; Dolukhanov, Timofeev 1993; Kul'kova, Mazurkievich, Dolukhanov 2001).

Pottery with pointed bases spread to the Baltic coast and is known from the site of Dabki, in northern Poland, where it is now considered as a local variant of the Ertebølle tradition (Czerniak, Kabacinski 2002). From there the pottery should have spread towards the west, where it appears in Pommerania around $5000 \mathrm{cal}$ BC and in southern Schleswig-Holstein around $5100 \mathrm{cal} \mathrm{BC} \mathrm{(Hartz,} \mathrm{Heinrich,} \mathrm{Lübke}$ 2002). While in Scandinavia the first indications of 


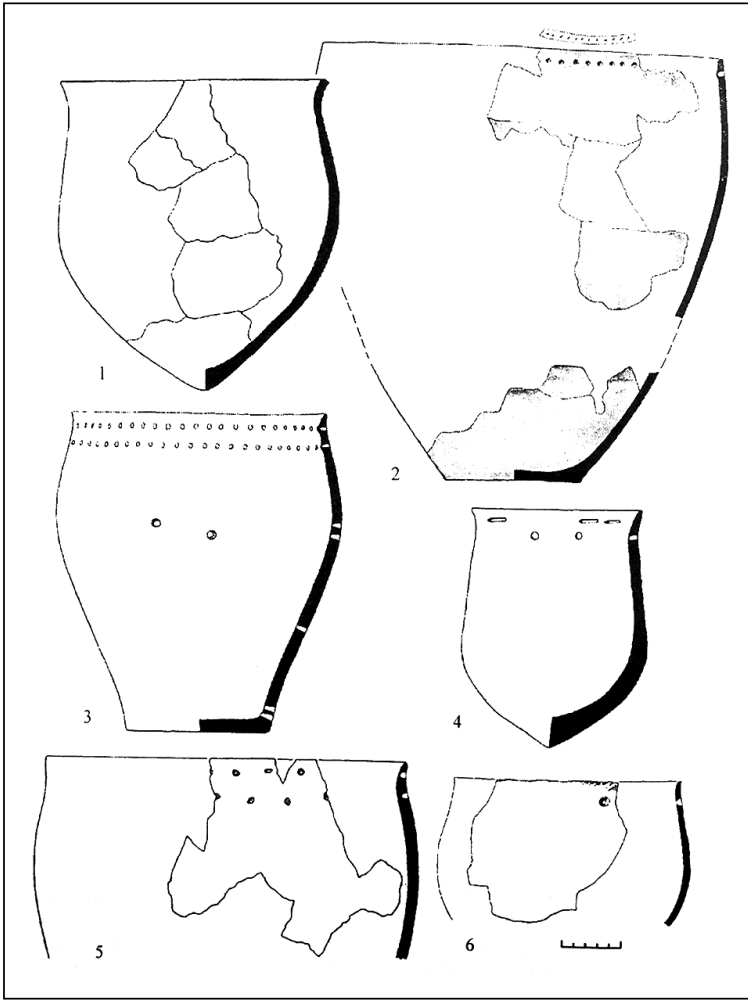

Fig. 6. Pottery from the Elshan Tradition (after Mamonov 2000).

a farming economy do not appear before $4200 \mathrm{cal}$ $\mathrm{BC}$, cereal horticulture is attested for Schleswig-Holstein between the $48^{\text {th }}$ and $46^{\text {th }}$ centuries cal BC; also, early cattle date to this period (Kalis, MeurersBalke 1998). Pottery spread from the Ertebølle region towards the west and has, for quite some time, been known from Dutch sites, for instance at Swifterbant (Raemakers 1999; Lowe Kooijmans 2001). But recently another group with a similar pottery, everted rims and pointed bases, has been announced from Belgian Flanders, here called the groupe de Melsele (Crombé 1999; Crombé et al. 2002; van Berg, van Royen, Keeley 1991; van Berg et al. 1992). ${ }^{14 C}$-Dates shift the early appearance of pottery to around $5000 \mathrm{cal} \mathrm{BC}$. All these sites have only produced remains of a hunter-gatherer subsistence mode (Van Neer et al. 2001). Lastly, Jeunesse and Lefranc (1999.44-47) have recently published a pointed base vessel from a pit in an LBK settlement which is dated between 5200 and 4800 cal BC (Fig. 7). The authors argue that this pottery might represent a ware stylistically related to the Ertbølle-tradition, a ware hitherto unrecorded in southern Central Europe. They discuss the possibility of a third indigenous ceramic component, different from La Hoguette and Limburg. Ultimately, while La Hoguette and perhaps also Limburg have stylistic resemblances in southern France (van Berg 1990a; van Berg 1990b), this third pottery tradition might have its stylistic ancestors in wares distributed in the Russian forest and steppe belts - a fascinating prospect for future research.

The Neolithization of Temperate Europe Revised

Since Vere Gordon Childe's (1936) coining of the term 'Neolithic Revolution' it has become habitual in western archaeology to think of the beginning of the Neolithic as the beginning of farming, and usually this is associated with the LBK or the "Danubian Tradition". Influenced by the functionalistic paradigm of the time and by contacts with Marxist archaeologists in the Soviet Union, Childe understood the adoption of farming and the concurrent technological and economic changes as fundamental prerequisites to social developments.

Before Childe's work, the Neolithic had been mainly defined on typological grounds, namely after Lubbock (1865), by the appearance of polished lithic artefacts. Later, pottery became part of the spectrum. This division of the Palaeolithic and Neolithic based on material culture and not on economic criteria has persisted in the Soviet Union and is still practiced in Russia today. The Neolithic here is perceived of as being constituted by the appearance of pottery, sedentism and a certain degree of implied social complexity (Dolukhanov 1995). So basically two apparently opposing definitions of the term "Neolithic"

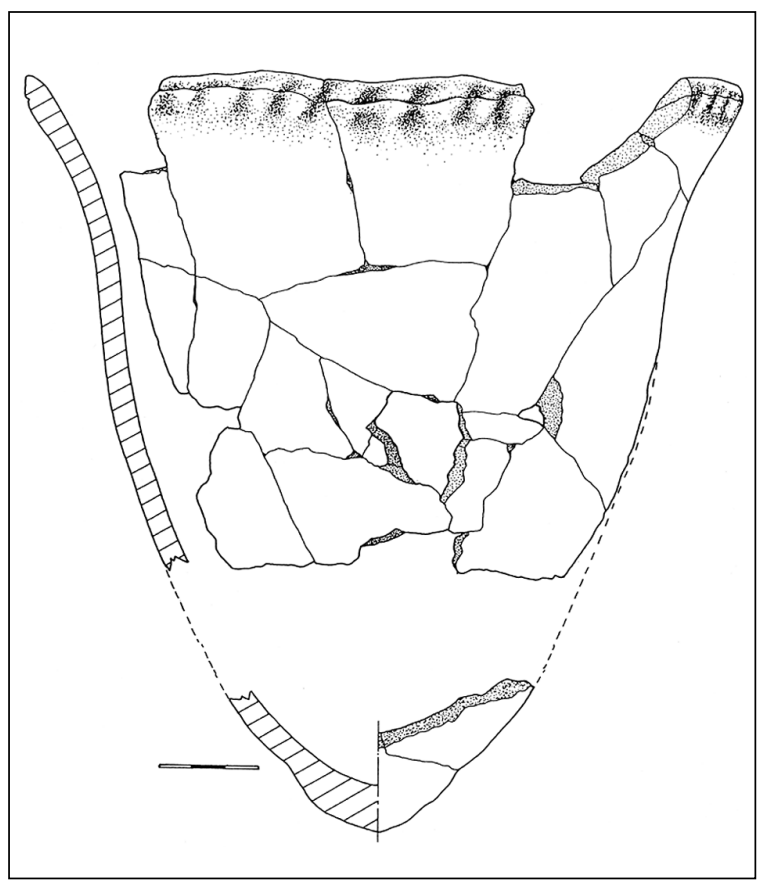

Fig. 7. Pointed base vessel from LBK settlement of Rosheim, Alsace (after Jeunesse and Lefranc 1999). 
co-exist in Europe (Dolukhanov 1998), one based on material culture, one based on economy.

The latter definition, though, begins to pose problems. How do we classify the societies that produced La Hoguette or Limburg pottery? Traditionally, they are subsumed under the term "Terminal Mesolithic" (Gronenborn 1999). But how would we see eLBK groups? The faunal material indicates that at least in some communities hunting still played a considerable, sometimes a dominant role (Uerpmann, Uerpmann 1997; Lüning 2000). And lately it has become clear that also later LBK villages were composed of social groups, of which some depended on farming, while others seem to have maintained more of a forager economy (Hachem 2000), a tradition which continues into the Middle Neolithc Period (Sidéra 2000). Perhaps these economic specializations within the societies have something to do with the composition of groups consisting of LBK lineages originating from Transdanubia and local hunter-gatherers. At least the evidence from the LBK site of Vaihingen does suggest such a relation (Krause et al. 1998). Here Strien (in press) was able to distinguish wards within the settlement which are characterized by differences in pottery decoration and also dif-
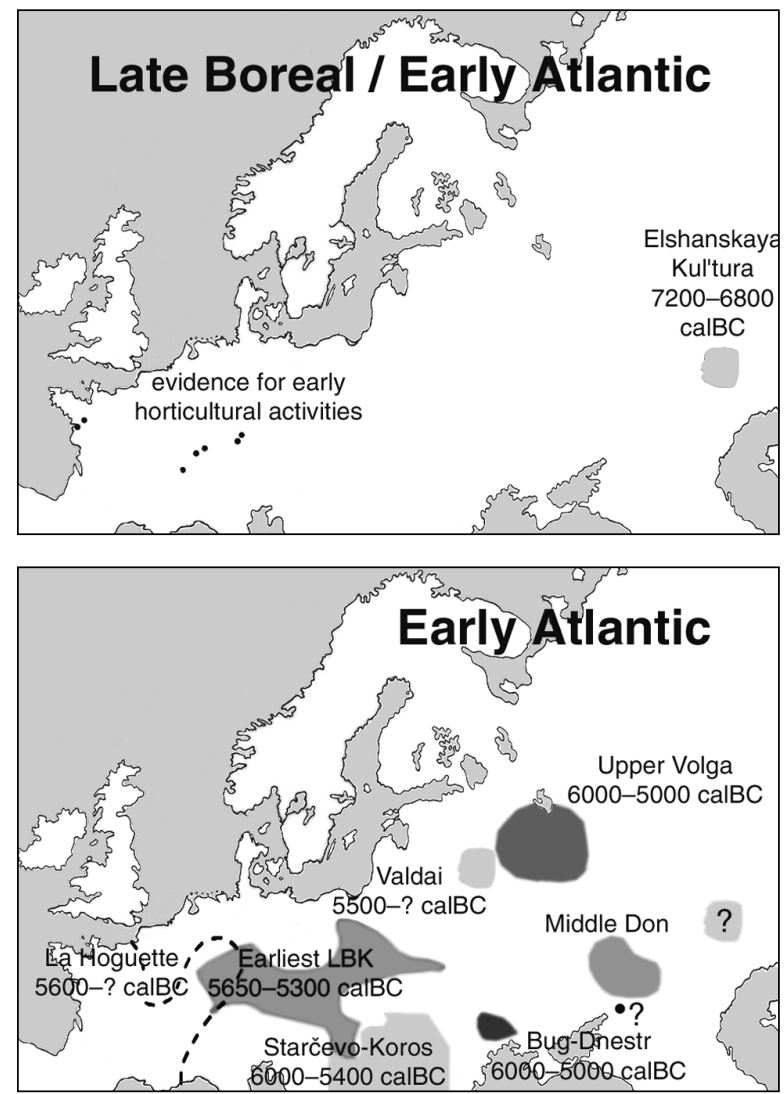

ferent microlith types. While some of these microlith types have a wide-ranging distribution, others have evolved out of the local Late Mesolithic tradition. The current interpretation of the pattern is that some lineages living in the settlement were descendents of immigrants from Transdanubia, while others were the heirs of those people who just a few generations before still led lives like the group that camped at Stuttgart-Bad Cannstatt. Apparently, the respective lineages practiced their traditional economy: some were full-scale farmers, while others continued with their transitional forager-horticulturalist way of life. Seemingly, the concept of what constitutes the "Neolithic" must go beyond a simple economic definition and entails socio-political aspects. Lately Renfrew (2001) has suggested seeing the demarcation line with the beginning of sedentism; however, what would we do with groups that practice some kind of transhumance, as has been suggested for LBK (Kalis, Zimmermann 1988)?

It is not my intention here to further embark on a terminological dispute about concepts of "The Neolithic" or "The Mesolithic". What I want to point out is that between the later $7^{\text {th }}$ millennium and, in some parts of Europe, well into the $4^{\text {th }}$ millennium, we are dea-
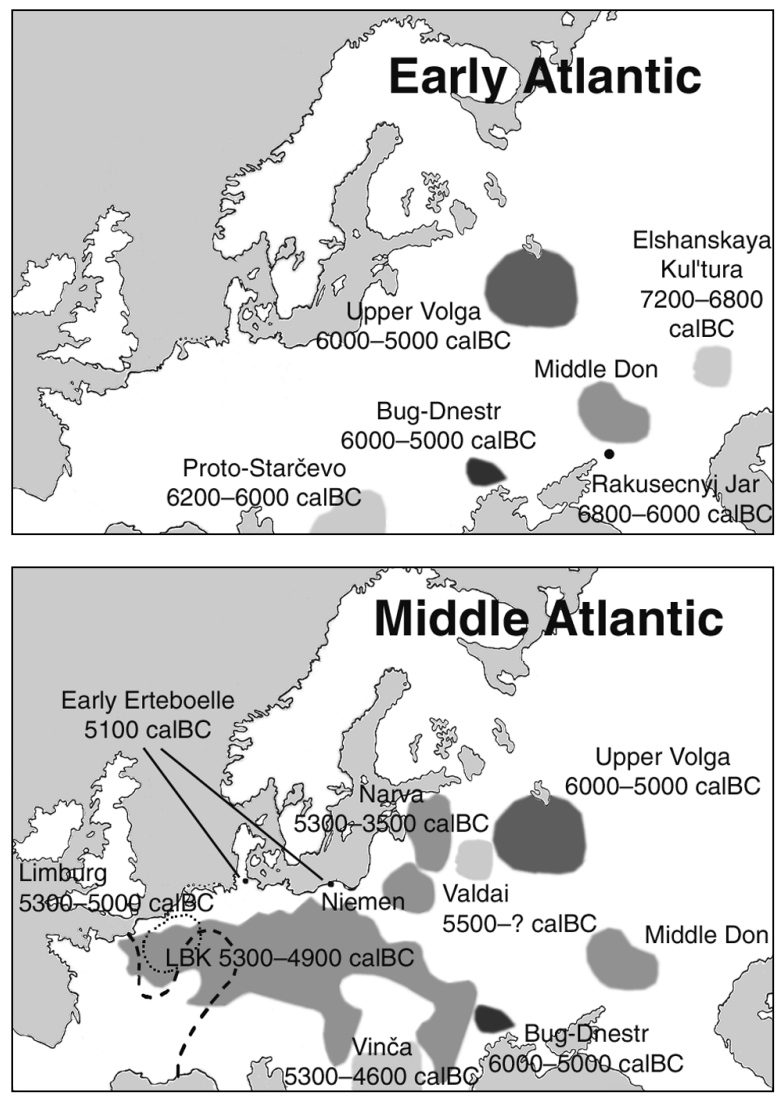

Fig. 8. Revised cartographic representation of the spread of pottery and farming in Temperate Europe and Eurasia. 
ling with a transitional period. What currently needs to be stressed is that the "Neolithization of Europe" is a much more complex process than hitherto imagined. This concerns at least three levels of resolution. At the village level we have to account for settlements inhabited by lineages of different cultural backgrounds. How close their ties were on the household level remains to be explored. Current evidence from Vaihingen (Strien in press) shows that the social units in this settlement were relatively stable throughout younger LBK, despite the evidence of inter-group fluctuations from other areas. On a regional level we see these - ethnic? - groups again, sharing the same general region, but exploring different economic niches within this region. And on a supra-regional level we may distinguish different horizons of the Neolithization processes, of which presently, admittedly at a very coarse level, we can differentiate three. All of these evolved out of Mesolithic networks (Gronenborn 1999), along which pottery styles and farming practices spread (Fig. 8)

The classical Central European network is the one which later evolved into the "Danubian Neolithic" in traditional terminology; the Western or Occidental system may have evolved out of the Mediterranean Neolithic, but also out of local antecedents. In any case, its territorial distribution is again oriented along Late Mesolithic network lines. Thirdly, we have to account for a "Neolithic" in Lubbock's sense, which follows contact networks in eastern Europe and which expands along the Baltic coastline into the north-western European lowlands. This northern to north-eastern facet of the chasseurs ceramisés- or subnéolithique-phenomenon (van Berg 1990; 1997) might be subsumed under the term "Hyperborean Horizon". While in Central Europe we gradually begin to understand the complex relationships and interactions between the Danubian and Occidental Horizons, the contribution of the "Russian connection" is still very much unclear, but should by no means be underestimated.

Research was partly financed by the INTAS grant
2000-00016 "Agricultural Prelude in Russian Fo-
rests" and a grant from the Römisch-Germanisches
Zentralmuseum Mainz, Germany. For comments on
the manuscript and unpublished material I am gra-
teful to Philippe Crombe, Gent (Belgium), Pavel Do-
lukhanov, Newcastle upon Tyne (UK), Lendeert Lou-
we Kooijmans, Leuven (The Netherlands), Andrei Ma-
zurkevich, St. Petersburg (Russia), Knut Rassmann,
Frankfurt/M. (Germany), who helped with the maps,
and Vladimir I. Timofeev, St. Petersburg (Russia).

\section{REFERENCES}

BÁNFFY E. 2000. Neue Daten zur Entstehung der Bandkeramik. In S. Hiller, V. Nikolov (eds.), Karanovo Band III. Beiträge zum Neolithikum in Südosteuropa: 375-382.

2000. Starčevo und/oder LBK? In H.-J. Beier (ed.), Varia Neolithica I. Beiträge zur Ur-und Frühgeschichte Mitteleuropas 22: 47-60.

2000. The Late Starčevo and the Earliest Linear Pottery Groups in Western Transdanubia. In M. Budja (ed.), 7 th Neolithic Studies. Documenta Praehistorica XXVII: 173-186.

BEDNARZ M. 2001. Acheminement du silex "chocolat" pendant le Janislawicien et au Néolithique ancien dans le bassin de la Vistule. In R. Kertész, J. Makkay (eds.), From the Mesolithic to the Neolithic. Proce- edings of the International Archaeological Conference held in the Damjanich Museum of Szolnok, September 22-27, 1996. Archaeolingua 11: 23-54.

BENTLEY R. A., PRICE T. D., LÜNING J., GRONENBORN D., WAHL J. and FULLAGAR P. D. 2002. Prehistoric migration in Europe: Strontium isotope analysis of early Neolithic skeletons. Current Anthropo$\log y$ 43(5): 799-804.

BOGUCKI P. 2000. How agriculture came to northcentral Europe. In T. D. Price (ed.), Europe's First Farmers: $197-218$.

BRUNNACKER M., REIFF W., SOERGEL E. and TAUTE W. 1967. Neolithische Fundschicht mit HarpunenFragmenten im Travertin von Stuttgart-Bad Cannstatt. Fundberichte Schwaben N. F. 18: 43-60. 
CAHEN D., KEELEY L. H., JADIN I., VAN BERG P.-L. 1990. Trois villages fortifiés du Rubané récent en Hesbaye liégois. In D. Cahen u. M. Otte (eds.), $R u$ bané \& Cardial. Actes du Colloque de Liège, novembre 1988. ERAUL 39: 125-146.

CHILDE G. 1936. Man Makes Himself. London: Watts.

CROMBÉ P. 1999. Vers une nouvelle chronologie absolue pour le Méolithique en Belgique. In A. Thévenin (ed.), L'Europe des derniers Chasseurs. Actes du 5 e Colloque International UISPP, Commission XII, Grenoble, 18-23 september 1995: 189-199.

CROMBÉ PH., PERDAEN Y., SERGANT J., VAN ROYEN J.-P. and VAN STRYDONCK M. 2002. The MesolithicNeolithic transition in the sandy lowlands of Belgium: new evidence. Antiquity 76: 699-706.

CZERNIAK L. and KABACINSKI J. 2002. The Ertebølle Culture in the Southern Baltic Coast. In D. Król (ed.), The Built Environment of Coast Areas during the Stone Age. A Symposium at the Centenary of Archaeological Excavations at Rzucewo (RzucewoGdansk) 4-9 October 1994. Gdansk: The Baltic SeaCoast Landscapes Seminar Session No. 1: 70-79.

DANILENKO V. N. 1969. Neolit Ukrainy. Kiev: Isdatel'stvo "Naukova Dumka".

DOLUKHANOV P. 1995. Archaeology in Russia and its impact on archaeological theory. In P. Ucko (ed.), Theory in Archaeology: a World Perspective: 342372.

DOLUKHANOV P. M., GEY N. A., MIKLYAYEV A. M. and MAZURKIEWICZ A. N. 1989. Rudnya-Serteya, a stratified dwelling-site in the Upper Duna Basin (a multidisciplinary research). Fennoscandia archaeologica 6: 23-27.

DOLUKHANOV P. M. and TIMOFEEV V. I. 1993. Est de L'Europe: La zone des forets. In J. K. Kozłowski (dir.) u. P.-L. Van Berg (coll.), Atlas du néolithique europeen. Vol. 1. L'Europe orientale. Études et recherches Archéologique de l'Université de Liège no. 45: 495-534.

DOLUKHANOV P. M. 1998. The Neolithic with a human face or dividing lines in Neolithic Europe? In L. Domanska and K. Jacobs (eds.), Beyond Balkanization. Baltic-Pontic Studies Vol. 5: 13-22.
ERNY-RODMANN C., GROSS-KLEE E., HAAS J. N., JACOMET S. and ZOLLER H. 1997. Früher "human impact" und Ackerbau im Übergangsbereich Spätmesolithikum-Frühneolithikum im schweizerischen Mitteland. Jahrbuch der Schweizerischen Gesellschaft für Ur- und Frühgeschichte 80: 27-56.

FARRUGIA J.P., GUICHARD Y., HACHEM L. 1996. Les ensembles funéraires Rubanés de Menneville "Derrière le Village" (Aisne). In P. Duhamel (dir.), $L a$ Bourgogne entre les Bassins Rhénan, Rhodanien et Parisien: Carrefour ou frontière? Actes du XVIIIe Collogue interrégional sur le Néolithique. Dijon 25-27 octobre 1991. Revue Archéologique de L'Est. Supplement 14:129-174.

GOODY J. 1958. The fission of domestic groups among the Lodagaba. In J. Goody (ed.), The Developmental Cycle in Domestic Groups: 53-91.

GRONENBORN D. 1990. Eine Pfeilspitze vom ältestbandkeramischen Fundplatz Friedberg-Bruchenbrücken in der Wetterau. Germania 68: 223-231.

1994. Überlegungen zur Ausbreitung der bäuerlichen Wirtschaft in Mitteleuropa - Versuch einer kulturhistorischen Interpretation ältestbandkeramischer Silexinventare. Praehistorische Zeitschrift 69/2: 135-151.

1997. Silexartefakte der ältestbandkeramischen Kultur. Mit einem Beitrag von Jean-Paul Caspar. Bonn: Universitätsforschungen zur prähistorischen Archäologie 37.

1999. A variation on a basic theme: The transition to farming in southern Central Europe. Journal of World Prehistory 13: 123-210.

HACHEM L. 2000. New observations on the Bandkeramik house and social organization. Antiquity 74 : 308-312.

HARTZ S. 1985. Kongemose-Kultur in Schleswig-Holstein? Offa 42: 35-56.

HARTZ S., HEINRICH D. and LÜBKE H. 2002. Coastal farmers - the neolithisation of northernmost Germany. In A. Fischer, K. H. Kristiansen (eds.), The Neolithisation of Denmark. 150 Years of Debate: 321-340.

JACOTTEY L. 1997. La couche 5 de Bavans (Doubs) et la fin du Mésolithique en Franche-Comté. In C. 
Jeunesse (ed.), Le Néolithique Danubien et ses marges entre Rhin et Seine. XXIIe Colloque Interrégional sur le Néolithique, Strasbourg 27-29 octobre 1995. Cahiers de l'Association pour la Promotion de la Recherche Archéologique en Alsace. Supplément $n^{\circ}$ 3: 313-325.

JEUNESSE C. 2000. Les composantes autochtone et danubienne en Europe Centrale et occidentale entre 5500 et 4000 av. J.-C.: contacts, transfers, acculturations. In Les derniers chasseurs-cuilleurs d'Europe occidentale, Actes du colloque international de Besançon, octobre 1998. Presses Universitaires FrancComtoises 361 à 378, Annales Littéraires 699, Série "Environnement, sociétés et archaéologie" 1: 361-378.

2001. Armatures asymétriques, régionalisation, acculturation. Contribution à l'étude des relations entre la Rubané et la composante autochtone dans l'oust de la sphère danubienne. In Préhistoire de la Grande Plaine du Nord de l'Europe. Actes du Colloque Chaire Francqui interuniversitaire au titre étranger. ERAUL 99: 147-165.

JEUNESSE C. and LEFRANC P. 1999. Rosheim "SainteOdile" (Bas-Rhin), un habitat rubané avec fossé d'enceinte. Première partie: les structures et la céramique. Cahiers de l'association pour la promotion de la recherche archéologique en Alsace 15: 1-111.

KALIS A. J. and ZIMMERMANN A. 1988. An integrative model for the use of different landscapes in Linearbandkeramik times. In J. L. Bintliff, D. A. Davidson, E. G. Grant (eds.), Conceptual Issues in Environmental Archaeology: 145-152.

KALIS A. J. and MEURERS-BALKE J. 1998. Die "Landnam"-Modelle von Iversen und Troels-Smith zur Neolithisierung des westlichen Ostseegebietes - ein Versuch zu ihrer Aktualisierung. Praehistorische Zeitschrift 73: 1-144.

KALIS A. J., MEURERS-BALKE J., VAN DER BORG K., VON DEN DRIESCH A., RÄHLE W., TEGTMEIER U., THIEMEYER H. 2001. Der La-Hoguette-Fundhorizont in der Wilhelma von Stuttgart-Bad Cannstatt. Anthrakologische, archäopalynologische, bodenkundliche, malakozoologische, radiometrische und säugetierkundliche Untersuchungen. In B. Gehlen, M. Heinen, A. Tillmann (eds.), Zeit-Räume. Gedenkschrift für Wolfgang Taute Band 2: 649-672.
KEELEY L. and CAHEN D. 1989. Early Neolithic forts and villages in Northeastern Belgium: a preliminary report. Journal of Field Archaeology 16: 157-176.

KRAUSE R., ARBOGAST R.-M., HÖNSCHEIDT S., LIENEMANN J., PAPADOPOULOS S., RÖSCH M., SIDÉRA I., SMETTAN H. W., STRIEN H.-C. and WELGE K. 1998. Die bandkeramischen Siedlungsgrabungen bei Vaihingen an der Enz, Kreis Ludwigsburg (Baden-Württemberg). Bericht der Römisch-Germanischen Kommission 79: 5-105.

KUBA R. 2001. Marking boundaries and identities: the precolonial expansion of segmentary societies in Southwestern Burkina Faso. In Proceedings of the International Symposium 1999. Berichte des Sonderforschungsbereichs 268 "Kulturentwicklung und Sprachgeschichte im Naturraum Westafrikanische Savanna" Band 14: 415-426.

KUL'KOVA M. A., MAZURKEVICH A. N., DOLUKHANOV P. M. 2001. Chronology and paleoclimate of Prehistoric sites in western Dvina-Lovat' area of northwestern Russia. Geochronometria 20: 87-94.

LENNEIS E. 2001. Keramik. In E. Lenneis, J. Lüning (eds.), Die altbandkeramischen Siedlungen von Neckenmarkt und Strögen. Universitätsforschungen zur prähistorischen Archäologie 82: 79-186.

LENNEIS E., STADLER P., WINDL H. 1996. Neue ${ }^{14} \mathrm{C}-$ Daten zum Frühneolithikum in Österreich. Préhistoire Européenne 8: 97-116.

LENNEIS E., STADLER P. 2002. 14C-Daten und Seriation altbandkeramischer Inventare. Archeologické rozhledy 54: 191-201.

LOUWE KO0IJMANS L. P. 2001. Synthese. In L. P. Louwe Kooijmans (ed.), Archeologie in de Betuweroute, Hardinxveld-Giessendam Polderweg. Een mesolithisch jachtkamp in het rivierengebied (5500-5000 v. Chr.). ROB Rapportage Archeologische Monumentenzorg 83: 441-470.

LUBBOCK J. 1865. Pre-historic Times, as Illustrated by Ancient Remains, and the Manners and Customs of Modern savages. London: Williams and Norgate.

LÜNING J., KLOOS U. and ALBERT S. 1989. Westliche Nachbarn der bandkeramischen Kultur: Die Keramikgruppen La Hoguette und Limburg. Mit Beiträgen von J. Eckert und Chr. Strien. Germania 67: 355393. 
LÜNING J. 2000. Steinzeitliche Bauern in Deutschland. Die Landwirtschaft im Neolithikum. Universitätsforschungen zur prähistorischen Archäologie 58. Bonn: Habelt.

MAMONOV A. E. 2000. Rannij Neolit. Elshanskaja Kultura. In P. S. Kabetov, Vasil'eb I. B, Dubman Z. L., Smirnov J. H., Chramkov L. B. (eds.), Istorija Samarskogo Powolsch'ja: 147-176.

MEIER-ARENDT W. 1972. Die Ältere und Mittlere Linienbandkeramik im westlichen Mitteleuropa. Ein Überblick. Fundamenta Va: 66-76.

MEURERS-BALKE J. and KALIS A. J. 2001. Früh-, altund jungneolithische Landnutzung -archäopalynologische Bearbeitung der Wilhelma-Travertine von Bad Cannstatt. In B. Gehlen, M. Heinen and A. Tillmann (eds.), Zeit-Räume.Gedenkschrift für Wolfgang Taute Band 2: 631-648.

PETRASCH J. 2000. "Seid fruchtbar und mehret euch und füllet die Erde und machet sie euch untertan": Überlegungen zur demographischen Situation der bandkeramischen Landnahme. Archäologisches Korrespondenzblatt 31(1): 13-26.

2002. Religion in der Jungsteinzeit. Glaube, der die Gemeinschaft zusammenhält. In Menschen, Zeiten, Räume. Archäologie in Deutschland. Begleitband zur gleichnamigen Ausstellung: 142145.

PIGGOTT S. 1965. Ancient Europe. Edinburgh: Edinburgh University Press.

PRICE T. D., BENTLEY R. A., LÜNING J. L., GRONENBORN D. and WAHL J. 2001. Prehistoric human migration in the Linearbandkeramik of Central Europe. Antiquity 75: 593-603.

RAEMAKERS D. C. M. 1999. The Articulation of a 'New Neolithic'. The Meaning of the Swifterbant Culture for the Process of Neolithisation in the Western Part of the North European Plain (49003400 BC). Leiden: Archaeological Studies Leiden University. Faculty of Archaeology, University of Leiden.

RENFREW C. 2001. Commodification and institution in group-oriented and individualizing societies. In W. G. Runciman (ed.), The Origin of Human Social Instutions. Proceedings of the British Academy 110: 93-117.
SAHLINS M. D. 1961. The segmentary lineage: an organization of predatory expansion. American Anthropologist 63, 1961: 322-345.

SCHMIDT B., GRUHLE W. 2003. Wuchshomogenität als ein neues Analyseverfahren zur Verbesserung der dendrochronologischen Datierungsmethode. Die Hölzer der neolithischen Brunnen von ErkelenzKückhoven, Zwenkau und Mohelnice sowie vom Fundplatz Kaster. In J. Eckert, U. Eisenhauer and A. Zimmermann (eds.), Archäologische Perspektiven. Analysen und Interpretationen im Wandel. Festschrift für Jens Lüning zum 65. Geburtstag. Internationale Archäologie Studia honoraria 20: 49-60.

SCHWEIZER A. 2001. Archäopalynologische Untersuchungen zur Neolithisierung der nördlichen Wetterau/Hessen. Dissertationes Botanicae 350 Berlin/ Stuttgart: Cramer.

SIDÉRA I. 2000. Animaux domestiques, bêtes sauvages et objets en matières animales du Rubané au Michelsberg. Gallia Préhistoire 42: 107-194.

STÄUBLE H. 1995. Radiocarbon dates of the earliest Neolithic in Central Europe. In G. T. Cook, D. D. Harkness, B. F. Miller and E. M. Scott (eds.), Proceedings of the $15^{\text {th }}$ International ${ }^{14} \mathrm{C}$ Conference. Radiocarbon 37/2: 227-237.

STÖCKLI W. 2002. Absolute und relative Chronologie des Früh- und Mittelneolithikums in Westdeutschland (Rheinland und Rhein-Main-Gebiet). Basler Hefte z. Arch. 1. DGUF-Verlag.

STRIEN H.-C., TILLMANN A. 2001. Die La-HoguetteFundstelle Stuttgart-Bad Cannstatt: Archäologie. In B. Gehlen, M. Heinen u. A. Tillmann (eds.), Zeit-Räume. Gedenkschrift für Wolfgang Taute Band 2: 673-681.

STRIEN H.-C. in press. Familientraditionen in der bandkeramischen Siedlung bei Vaihingen/Enz. Proceedings of the Symposium Die Bandkeramik im 21. Jahrhundert, Brauweiler bei Köln, September 2002.

TICHY R. 1998. The context of the Early-LBK well at Mohelnice. In H. Koschik (ed.), Brunnen der Jungsteinzeit. Internationales Symposium in Erkelenz 27. bis 29. Oktober 1997: 45-50.

TIMOFEEV V. I. 1998a. The Beginning of the Neolithic in the Eastern Baltic. In M. Zvelebil, L. Domanska and R. Dennell (eds.), Harvesting the Sea, Far- 
ming the Forest. The Emergence of Neolithic Societies in the Baltic Region: 225-236.

1998b. The east - west relations in the Late Mesolithic and Neolithic in the Baltic Region. In L. Domanska and K. Jacobs (eds.), Beyond Balkanization. Baltic-Pontic Studies Vol. 5: 44-58.

UERPMANN H.-P. 1983. Die Anfänge von Tierhaltung und Pflanzenanbau. In H. Müller-Beck (ed.), Urgeschichte in Baden-Württemberg: 405-428.

UERPMANN M. and UERPMANN H. P. 1997. Remarks on the faunal remains of some early farming communities in Central Europe. Anthropozoologica 25/ 26: 571-578.

VAN BERG P.-L. 1990 a. Céramique du Limbourg et Néolithisation en Europe du Nord-Ouest. In D. Cahen and M. Otte (eds.), Rubané \& Cardial. Actes du colloque de Liège, novembre 1988. Études et Recherches Archéologiques de l'Université de Liège 39: 161-208.

1990 b. La ceramique Néolithique Ancienne non rubanée dans le nord-ouest de l'Europe. Bulletin de la Societé Préhistorique Luxembourg 12: 107-124.

VAN BERG P.-L., VAN ROEYEN J.-P., KEELEY L. H. 1991. Le site a cèramique de Melsele (Flandre-Orientale), Campagne de 1990. Notae Praehistoricae 10: 37-47.

VAN BERG P-L., KEELEY L., VAN ROEYEN J-P., VAN HOVE R. 1992. Le gisement Mésolithique de Melsele (Flandre-Orientale, Belgique) et le Subnéolithique en Europe Occidentale. In Ch-T. Le Roux (ed.), Paysans et Batisseurs. L'emergence du neolithique Atlantique et les origines du megalithisme. Actes du $17 e ̀ m e$ Colloque interrérionale sur le Néolithique Vannes, 28-31 oct. 1990. Revues Archéologique de l'Ouest, supplément $n^{\circ}$ : 93-99.
VAN BERG P.-L. 1997. La céramique et son décor en Eurasie In Chr. Jeunesse (ed.), Le Néolithique Danubien et ses marges entre Rhin et Seine. XXIIe Colloque Interrégional sur le Néolithique, Strasbourg 27-29 octobre 1995. Cahiers de l'Association pour la Promotion de la Recherche Archéologique en Alsace. Supplément $n^{\circ}$ 3: 223-264.

VAN NEER W., ERVYNCK A., LENTACKER A., CROMBÉ P., SERGANT J., PERDAEN Y., VAN STRYDONCK M., VAN ROEYEN J-P. 2001. Dierenresten uit een vroege Swifterbant-nederzetting te Doel-Deurganckdok (Vlaanderen, België): jachtweld, maar vooral veel vis. Notae Praehistoricae 21: 85-96.

VISSET L., CYPRIEN A.-L., CARCAUD N., OUGUERRAM A., BARBIER D., BERNARD J. 2002. Les prémices d'une agriculture diversifiée à la fin du Mésolithique dans le Val de Loire (Loire armoricaine, France). $C a$ hiers Revistes Palevol 1, 2002, 51-58.

WECHLER K.-P. 2001. Studien zum Neolithikum der osteuropäischen Steppe. Deutsches Archäologisches Institut. Eurasien-Abteilung. Mainz: von Zabern.

ZILHÃO J. 2001. Radiocarbon evidence for maritime pioneer colonization at the origins of farming in west Mediterranean Europe. Proceedings of the National Academy of Sciences of the United States of America 98: 1480-1485.

ZIMMERMANN A. 2002. Der Beginn der Landwirtschaft in Mitteleuropa. Evolution oder Revolution? In M. Nawroth, R. von Schnurbein, R.-M. Weiss and M. Will (eds.), Menschen - Zeiten - Räume. Archäologie in Deutschland. Begleitband zur gleichnamigen Ausstellung. Konrad Theiss: 133-135.

ZVELEBIL M. and DOLUKHANOV P. 1991. The transition to farming in eastern and northern Europe. Journal of World Prehistory 5/3: 233-278. 